\title{
ANALISIS FAKTOR - FAKTOR YANG BERHUBUNGAN DENGAN KINERJA PERAWAT DALAM MENERAPKAN ASUHAN KEPERAWATAN DI RUMAH SAKIT UMUM BETHESDA GMIM TOMOHON
}

\author{
${ }^{1}$ Fergie M. Mandagi \\ ${ }^{2}$ Jootje M. L. Umboh \\ ${ }^{3}$ Joy A. M. Rattu \\ ${ }^{1}$ Program Pasca Sarjana Program Studi Ilmu Kesehatan Masyarakat \\ ${ }^{2}$ Ilmu Kesehatan Masyarakat \\ ${ }^{3}$ Bagian Fisiologi Fakultas Kedokteran \\ Universitas Sam Ratulangi Manado \\ E-mail: fergiemandagi@yahoo.com
}

\begin{abstract}
The performance of nurses at the inpatient room in General Hospital Bethesda GMIM Tomohon can be seen from the quality of nursing care. The performance of nurses in implementing nursing care is a quality indicator at a hospital. This study aimed to determine the relationship between motivation, competence, supervision and appreciation to the performance of nurses in implementing nursing care at the General Hospital Bethesda GMIM Tomohon. This was an observational study with a case control design. The case samples were the executive nurses at the inpatient room. The sampling method that was used was Lemenshow formula. The data were collected from questionnaire and observation sheet, and be analyzed with the chi-square bivariate and multivariate logistic regression test. The results showed that there was a significant relationship between motivation (OR 6,98, $\mathrm{p}=0,004)$, supervision (OR 4,69, $\mathrm{p}=0,019$ ), and appreciation (OR 19,79, $\mathrm{p}=0,000$ ) to the performance of nurses, meanwhile competence (OR 1,91, $\mathrm{p}=0,409$ ) had no significant relationship with the performance of nurses. The multivariate analysis showed that appreciation was the most dominant variable that affected the performance with an Odds Ratio 16.513 and statistically significant $(\mathrm{p}=0.004)$. The nurse's performance was associated with motivation, supervision and appreciaton. Therefore, those aspects that affect motivation, supervision and appreciaton of work need to be managed properly in order to achieve the best performance of nurses.
\end{abstract}

Keywords: motivation, competence, supervision, apreciation, performance, nurse

\begin{abstract}
Abstrak: Kinerja perawat di ruangan inap Rumah Sakit Umum Bethesda GMIM Tomohon dapat ditentukan dari mutu asuhan keperawatan yang diberikan. Kinerja perawat dalam menerapkan asuhan keperawatan merupakan indikator mutu pada suatu rumah sakit. Penelitian ini bertujuan untuk mengetahui hubungan antara motivasi, kompetensi, supervisi dan penghargaan dengan kinerja perawat dalam menerapkan asuhan keperawatan di Rumah Sakit Umum Bethesda GMIM Tomohon. Metode yang digunakan dalam penelitian ini yaitu observasional dengan rancangan penelitian kasus kontrol. Sampel kasus dalam penelitian ini yaitu perawat pelaksana di ruang inap. Pengambilan sampel menggunakan rumus Lemenshow. Data dikumpulkan dengan kuesioner dan lembar observasi, kemudian dianalisis bivariat dengan chi-square dan multivariat dengan uji regresi logisik. Hasil penelitian didapatkan bahwa terdapat hubungan bermakna antara motivasi (OR 6,98, $\mathrm{p}=0,004)$, supervisi (OR 4,69, $\mathrm{p}=0,019)$ dan penghargaan (OR 19,79, $\mathrm{p}=0,000$ ) dengan kinerja perawat, sedangkan kompetensi (OR 1,91, $\mathrm{p}=0,409$ ) tidak terdapat hubungan bermakna dengan kinerja perawat. Analisis multivariat menunjukkan aspek penghargaan merupakan variabel paling dominan
\end{abstract}


mempengaruhi kinerja dengan nilai Odds Ratio 16,513 dan bermakna secara statistik $(\mathrm{p}=0,004)$. Kinerja perawat sangat berhubungan dengan motivasi, supervisi dan penghargaan kerja perawat, sehingga aspek-aspek yang memengaruhi motivasi, supervisi dan penghargaan kerja perlu dikelola dengan baik untuk mendapatkan hasil kinerja perawat yang baik.

Kata kunci: motivasi, kompetensi, supervisi, penghargaan, kinerja, perawat

Tenaga kesehatan sebagai sumber daya manusia dalam menjalankan pelayanan kesehatan di rumah sakit merupakan sumber daya yang penting dan sangat di butuhkan untuk mencapai kinerja yang optimal. $^{1} \quad$ Berhasil tidaknya suatu perusahaan termasuk perusahaan yang bergerak dalam bidang jasa pelayanan kesehatan seperti rumah sakit tergantung pada kemampuan sumber daya manusia dalam menjalankan aktivitasnya. ${ }^{2}$

Pelayanan kesehatan di Indonesia, khususnya pelayanan kesehatan di rumah sakit saat ini sedang mendapat perhatian dari masyarakat. Pelbagai keluhan dari masyarakat yang menyangkut kualitas pelayanan di rumah sakit haruslah mendapat kepedulian dari pihak pengelola dan penyelenggara layanan rumah sakit. Kendala manajemen dan pelaksanaannya perlu untuk segera diatas atau diminimalkan. ${ }^{3}$

Kinerja (performance) menjadi isu dunia saat ini. Hal tersebut terjadi sebagai konsekuensi tuntutan masyarakat terhadap kebutuhan akan pelayanan prima atau pelayanan yang bermutu tinggi yang tidak terpisahkan dari standar, karena kinerja diukur berdasarkan standar. Perawat diharapkan dapat menunjukkan kontribusi profesionalnya secara nyata dalam meningkatkan mutu keperawatan, yang berdampak terhadap pelayanan kesehatan secara umum pada organisasi tempatnya bekerja, dan dampak akhir bermuara pada kualitas hidup dan kesejahteraan masyarakat. ${ }^{4}$ Salah satu metode dalam menilai kinerja perawat yaitu dengan melihat standar asuhan keperawatan. Standar asuhan keperawatan adalah suatu pernyataan yang menguraikan kualitas yang diinginkan terkait dengan pelayanan keperawatan terhadap klien. ${ }^{5}$

Gibson menyatakan bahwa kinerja individu perawat dipengaruhi oleh 3 variabel yaitu variabel individu, variabel organisasi dan variabel psikologis. ${ }^{6}$ Variabel individu, terdiri dari kemampuan, keterampilan, pengetahuan, demografi dan latar belakang keluarga. Variabel psikologi terdiri dari persepsi, sikap, motivasi, kepribadian dan belajar. Variabel organisasi terdiri dari sumber daya, imbalan, beban kerja, struktur, supervisi dan kepemimpinan. Kinerja klinis perawat dipengaruhi oleh faktor internal dan faktor eksternal, faktor internal adalah keterampilan dan motivasi perawat, sedangkan faktor eksternal adalah supervisi, gaya kepemimpinan dan monitoring. ${ }^{7}$

RSU Bethesda GMIM merupakan rumah sakit umum tipe $C$ yang ada di Kota Tomohon dengan kapasitas berisi 224 tempat tidur. RSU Bethesda GMIM Tomohon meliputi pelayanan 4 spesialisasi dasar dan spesialisasi lainnya baik untuk rawat jalan maupun rawat inap. Tenaga keperawatan yang ada di RSU Bethesda GMIM Tomohon dari hasil data bulan Oktober 2015 terakhir ialah sebanyak 180 orang seluruhnya. Tingkat pendidikan Ns sebanyak 15 orang, S1 sebanyak 6 orang, D4 sebanyank 4 orang, D3 sebanyak 88 orang, D1 sebanyak 3 orang dan SPK sebanyak 64 orang.

Data yang ada menunjukkan bahwa perawat di RSU Bethesda GMIM Tomohon belum memperlihatkan kinerja yang maksimal. Hal ini terlihat dari penerapan asuhan keperawatan di ruangan inap RSU Bethesda GMIM Tomohon dari bulan Desember 2013, yaitu dari 3934 Berkas Status Pasien yang ada, hanya 702 berkas yang terisi lengkap, sedangkan 3232 berkas lainnya tidak terisi lengkap, ini menunjukkan bahwa pengisian format secara lengkap sebesar 17,8\%, sedangkan 
yang tidak lengkap adalah 82,2\%. Pengisian format merupakan indikator penerapan asuhan keperawatan. Beberapa hal juga yang ditemui adalah banyak implementasi keperawatan yang dilakukan tidak maksimal. Penelitian ini bertujuan untuk menganalisis faktor-faktor yang berhubungan dengan kinerja perawat dalam menerapkan asuhan keperawatan di RSU Bethesda GMIM Tomohon.

\section{METODE PENELITIAN}

Penelitian ini menggunakan metode observational analitik dengan pendekatan potong lintang yang menjelaskan hubungan variabel dalam penelitian ini, yakni metode pengambilan data yang dilakukan dalam waktu bersamaan. Tujuan metode ini agar diperoleh daya yang lengkap dalam waktu yang relatif singkat.

Penelitian ini dilaksanakan dibagian rawat inap RSU GMIM Bethesda Tomohon pada bulan September 2015 sampai bulan November 2015. Populasi perawat yang bekerja di ruang rawat inap RSU Bethesda GMIM Tomohon yang berjumlah 95 orang Perawat Pelaksana. Besar sampel minimal digunakan rumus perhitungan sampel dengan besar sampel untuk proporsi tunggal karena $\mathrm{N}$ sudah diketahui, maka perhitungan besar sampelnya dihitung dengan rumus Lemeshow di dapati 58 orang. Variabel Tergantung pada penelitian ini adalah Kinerja Perawat dalam penerapan asuhan keperawatan dan Variabel Bebas pada penelitian ini adalah Motivasi, Kompetensi, Supervisi dan Penghargaan. Data primer yang dikumpulkan melalui kuesioner dan observasi terhadap responden sesuai dengan besar sampel perawat di rawat inap RSU Bethesda GMIM Tomohon dan data sekunder diperoleh dari bagian catatan medik dan observasi kinerja perawat di RSU Bethesda GMIM Tomohon. Sebagai alat ukur untuk mengumpulkan data dalam penelitian ini dugunakan jenis instrumen kuesioner daftar pertanyaan atau pernyataan mengenai faktor-faktor yang berhubungan dengan kinerja perawat di RSU Bethesda GMIM Tomohon. Proses penentuan nilai setiap poin pertanyaan menggunakan metode Linkert Summated Ratings (LRS). Data yang diperoleh dianalisis menggunakan uji chi-square dan uji regresi logistik.

\section{HASIL PENELITIAN Hasil Uji Bivariat}

a. Hubungan antara Motivasi Perawat dengan Kinerja Perawat dalam Menerapkan Asuhan Keperawatan di RSU Bethesda GMIM Tomohon

Data pada Tabel 1 menunjukkan bahwa dari 31 responden dengan motivasi yang baik, 29,3\% memiliki kinerja yang baik sedangkan kinerja kurang baik sebanyak 24,1\%. Data juga menunjukkan bahwa dari 27 responden dengan motivasi kurang baik, 6,9\% memiliki kinerja yang baik sedangkan 39,7\% memiliki kinerja yang kurang baik. Dilihat dari nilai signifikansi sebesar 0,004 dengan demikian probabilitas (signifikansi) lebih kecil dari $0,05(0,004<0,05)$, maka H1 diterima atau ada hubungan antara motivasi perawat dengan kinerja perawat. Dilihat dari OR (Odds Ratio) menunjukkan bahwa motivasi perawat yang baik akan membuat kinerja baik sebesar 6,9 kali lebih besar dibandingkan motivasi perawat yang kurang baik.

b. Hubungan antara Kompetensi Perawat dengan Kinerja Perawat dalam Menerapkan Asuhan Keperawatan di RSU Bethesda GMIM Tomohon

Data pada Tabel 2 menunjukkan bahwa dari 36 responden dengan kompetensi yang baik, 25,9\% memiliki kinerja yang baik sedangkan kinerja kurang baik sebanyak 36,2\%. Data juga menunjukkan bahwa dari 22 responden dengan kompetensi kurang baik,10,3\% memiliki kinerja yang baik sedangkan 27,6\% memiliki kinerja yang kurang baik. Dilihat dari nilai signifikansi sebesar 0,409 dengan demikian probabilitas (signifikansi) lebih besar dari 0,05 (0,409>0,05), maka H1 ditolak atau tidak ada hubungan antara kompetensi perawat dengan kinerja perawat. 
Mandagi, Umboh, Rattu: Analisis faktor-faktor...

Tabel 1. Hubungan antara Motivasi Perawat dengan Kinerja Perawat dalam Menerapkan Asuhan Keperawatan di Rumah Sakit Umum Bethesda GMIM Tomohon

\begin{tabular}{|c|c|c|c|c|c|c|c|c|}
\hline \multirow{3}{*}{ Motivasi } & \multicolumn{4}{|c|}{ Kinerja } & \multirow{3}{*}{ Total } & \multirow{3}{*}{$\%$} & \multirow{3}{*}{$\begin{array}{c}\text { OR } \\
(95 \% \mathrm{CI})\end{array}$} & \multirow{3}{*}{ Nilai p } \\
\hline & \multicolumn{2}{|c|}{ Baik } & \multicolumn{2}{|c|}{$\begin{array}{c}\text { Kurang } \\
\text { Baik }\end{array}$} & & & & \\
\hline & $\mathrm{n}$ & $\%$ & $\mathrm{n}$ & $\%$ & & & & \\
\hline Baik & 17 & 29,3 & 14 & 24,1 & 31 & 53,4 & & \\
\hline Kurang Baik & 4 & 6,9 & 23 & 39,7 & 27 & 46,6 & $\begin{array}{c}6,98 \\
(1,95-25,01)\end{array}$ & 0,004 \\
\hline Total & 21 & 36,2 & 37 & 63,8 & 58 & 100,0 & (95-25,01) & \\
\hline
\end{tabular}

Tabel 2. Hubungan antara Kompetensi Perawat dengan Kinerja Perawat dalam Menerapkan Asuhan Keperawatan di Rumah Sakit Umum Bethesda GMIM Tomohon

\begin{tabular}{|c|c|c|c|c|c|c|c|c|}
\hline \multirow{3}{*}{ Kompetensi } & \multicolumn{4}{|c|}{ Kinerja } & \multirow{3}{*}{ Total } & \multirow{3}{*}{$\%$} & \multirow{3}{*}{$\begin{array}{c}\text { OR } \\
(95 \% \text { CI })\end{array}$} & \multirow{3}{*}{ Nilai p } \\
\hline & \multicolumn{2}{|c|}{ Baik } & \multicolumn{2}{|c|}{$\begin{array}{c}\text { Kurang } \\
\text { Baik }\end{array}$} & & & & \\
\hline & $\mathrm{N}$ & $\%$ & $\mathrm{~N}$ & $\%$ & & & & \\
\hline Baik & 15 & 25,9 & 21 & 36,2 & 36 & 62,1 & & \\
\hline Kurang Baik & 6 & 10,3 & 16 & 27,6 & 22 & 37,9 & $\begin{array}{c}1,91 \\
(0,60-60)\end{array}$ & 0,409 \\
\hline Total & 21 & 36,2 & 37 & 63,8 & 58 & 100,0 & & \\
\hline
\end{tabular}

Tabel 3. Hubungan antara Supervisi Pimpinan dengan Kinerja Perawat dalam Menerapkan Asuhan Keperawatan di Rumah Sakit Umum Bethesda GMIM Tomohon

\begin{tabular}{|c|c|c|c|c|c|c|c|c|}
\hline \multirow{3}{*}{ Supervisi } & \multicolumn{4}{|c|}{ Kinerja } & \multirow{3}{*}{ Total } & \multirow{3}{*}{$\%$} & \multirow{3}{*}{$\begin{array}{c}\text { OR } \\
(95 \% \mathrm{CI})\end{array}$} & \multirow{3}{*}{ Nilai p } \\
\hline & \multicolumn{2}{|c|}{ Baik } & \multicolumn{2}{|c|}{$\begin{array}{c}\text { Kurang } \\
\text { Baik }\end{array}$} & & & & \\
\hline & $\mathrm{n}$ & $\%$ & $\mathrm{n}$ & $\%$ & & & & \\
\hline Baik & 16 & 27,6 & 15 & 25,9 & 31 & 53,4 & & \\
\hline Kurang Baik & 5 & 8,6 & 22 & 37,9 & 27 & 46,6 & $\begin{array}{c}4,69 \\
(1,41-15,58)\end{array}$ & 0,019 \\
\hline Total & 21 & 36,2 & 37 & 63,8 & 58 & 100,0 & & \\
\hline
\end{tabular}

c. Hubungan antara Supervisi Pimpinan dengan Kinerja Perawat dalam Menerapkan Asuhan Keperawatan di RSU Bethesda GMIM Tomohon

Data pada Tabel 3 di atas menunjukkan bahwa dari 31 responden dengan supervisi yang baik 27,6\% memiliki kinerja yang baik sedangkan kinerja kurang baik sebanyak 25,9\%. Data juga menunjukkan bahwa dari 27 responden dengan supervisi kurang baik $8,6 \%$ memiliki kinerja yang baik sedangkan 37,9\% memiliki kinerja yang kurang baik. Dilihat dari nilai signifikansi sebesar 0,019 dengan demikian probabilitas (signifikansi) lebih kecil dari 0,05 $(0,019<0,05)$, maka H1 diterima atau ada hubungan antara supervisi perawat dengan kinerja perawat. NIlai OR (Odds Ratio) menunjukkan bahwa supervisi perawat yang baik akan membuat kinerja baik sebesar 4,7 kali lebih besar dibandingkan supervisi perawat yang kurang baik.

d. Hubungan antara Penghargaan Perawat dengan Kinerja Perawat dalam Menerapkan Asuhan Keperawatan di RSU Bethesda GMIM Tomohon

Data pada Tabel 4 di atas menunjukkan bahwa dari 31 responden dengan penghargaan yang baik, 32,8\% memiliki kinerja yang baik sedangkan kinerja kurang baik sebanyak 20,7\%. Data juga menunjukkan bahwa dari 27 
responden dengan penghargaan kurang baik,3,4\% memiliki kinerja yang baik sedangkan 43,1\% memiliki kinerja yang kurang baik. Dilihat dari nilai signifikansi sebesar 0,000 dengan demikian probabilitas (signifikansi) lebih kecil dari 0,05 $(0,000<0,05)$, maka H1 diterima atau ada hubungan antara penghargaan perawat dengan kinerja perawat. Nilai OR menunjukkan bahwa sistem penghargaan perawat yang baik akan membuat kinerja baik sebesar 19,79 kali lebih besar dibandingkan penghargaan perawat yang kurang baik.

\section{Hasil Uji Multivariat}

Hasil uji bivariat menghasilkan nilai p dari variabel motivasi, supervisi dan sistem penghargaan terhadap kinerja perawat di bawah 0,25 (Tabel 5).

Selanjutnya dilakukan analisis multivariat variabel motivasi, supervisi dan penghargaan. Uji dilakukan dengan analisis regresi logistik untuk mengetahui variabel yang paling berpengaruh terhadap kinerja perawat. Hasil akhir uji multivariat dengan menggunakan regresi logistik dapat dilihat pada Tabel 6 yang menunjukkan bahwa penghargaan merupakan variabel yang paling berperan terhadap kinerja perawat dengan nilai $\mathrm{OR}=16,5(\mathrm{CI} 95 \%=3,4-$ 91,0) dibandingkan supervisi $(\mathrm{OR}=0,4$; $\mathrm{CI}$ $95 \%=0,0-3,9)$. Hal ini berarti dengan perawat dengan penghargaan yang baik kemungkinan 16,5 kali akan membuat kinerja baik dibandingkan sistem penghargaan yang tidak baik.

Tabel 4. Hubungan antara Penghargaan Perawat dengan Kinerja Perawat dalam Menerapkan Asuhan Keperawatan di Rumah Sakit Umum Bethesda GMIM Tomohon

\begin{tabular}{|c|c|c|c|c|c|c|c|c|}
\hline \multirow{3}{*}{ Penghargaan } & \multicolumn{4}{|c|}{ Kinerja } & \multirow{3}{*}{ Total } & \multirow{3}{*}{$\%$} & \multirow{3}{*}{$\begin{array}{c}\text { OR } \\
(95 \% \mathrm{CI})\end{array}$} & \multirow{3}{*}{ Nilai p } \\
\hline & \multicolumn{2}{|c|}{ Baik } & \multicolumn{2}{|c|}{$\begin{array}{c}\text { Kurang } \\
\text { Baik }\end{array}$} & & & & \\
\hline & $\mathrm{n}$ & $\%$ & $\mathrm{n}$ & $\%$ & & & & \\
\hline Baik & 19 & 32,8 & 12 & 20,7 & 31 & 53,4 & & \\
\hline KurangBaik & 2 & 3,4 & 25 & 43,1 & 27 & 46,6 & $\begin{array}{c}19,19 \\
(305-9016)\end{array}$ & 0,000 \\
\hline Total & 21 & 36,2 & 37 & 63,8 & 58 & 100,0 & & \\
\hline
\end{tabular}

Tabel 5. Hasil Seleksi Bivariat Penelitian

\begin{tabular}{lcc}
\hline Variabel & P value & OR \\
\hline Motivasi & 0,004 & 6,98 \\
Kompetensi & 0,409 & 1,91 \\
Supervisi & 0,019 & 4,69 \\
Penghargaan & 0,000 & 19,79 \\
\hline
\end{tabular}

Tabel 6. Hasil Akhir Analisis Regresi Logistik

\begin{tabular}{lccccc}
\hline \multirow{2}{*}{ Variabel } & \multirow{2}{*}{ S. E } & \multirow{2}{*}{ Sig } & \multirow{2}{*}{ OR } & \multicolumn{2}{c}{ 95\% C.I } \\
\cline { 5 - 6 } & & & & Lower & Upper \\
\hline Penghargaan & 1,28 & 0,004 & 16,513 & 3,357 & 91,006 \\
Supervisi & 1,17 & 0,424 & 0,394 & 0,040 & 3,870 \\
\hline
\end{tabular}




\section{BAHASAN}

a. Hubungan antara Motivasi Perawat dengan Kinerja Perawat dalam Menerapkan Asuhan Keperawatan di Rumah Sakit Umum Bethesda GMIM Tomohon

Berdasarkan hasil analisis bivariat dengan menggunakan uji Chi-square didapat bahwa nilai $\mathrm{p}=0,004$. Nilai $\mathrm{p}<$ 0,05 menunjukkan bahwa terdapat hubungan yang signifikan antara motivasi perawat dengan kinerja perawat dalam menerapkan asuhan keperawatan di Rumah Sakit Umum Bethesda GMIM Tomohon.

Motivasi yang dimiliki perawat dilihat dari hasil observasi adalah baik, perawat melakukan tugas dengan cepat tanggap dan terlihat bersemangat, dari kinerja yang dilakukan perawat terlihat baik didukung dengan peneliti mewawancarai pasien tentang kinerja perawat, pasien mengatakan puas dengan pelayanan yang diberikan perawat dan pasien mengatakan secara umum pelayanan kinerja perawat dirumah sakit ini baik, dengan seringnya dilakukan evaluasi dirumah sakit ini menunjukkan tugas perawat terkontrol dan terarah.

Motivasi merupakan perasaan atau pikiran yang mendorong seseorang melakukan pekerjaan atau menjalankan kekuasaan terutama dalam berperilaku agar seseorang dapat memenuhi kebutuhan dan keinginanya tidaklah mudah didapat apabila tanpa usaha yang maksimal. Dalam memenuhi kebutuhanya seseorang akan berperilaku sesuai dengan dorongan yang dimiliki dan apa yang mendasari perilakunya, dengan demikian dapat dikatakan bahwa dalam diri seseorang ada kekuatan. Motivasi yang memberikan kekuatan seseorang berperilaku dapat berasal dari interen ataupun eksteren. Teori motivasi memberikan penjelasan tentang kebutuhan dan keinginan seseorang serta menunjukan arah tindakannya. ${ }^{8}$

Motivasi yang juga merupakan kondisi dari perawat tersebut yang bisa mendorong seorang perawat untuk berperilaku menuju tujuan yang ingin dicapainya. Motivasi juga bisa membuat seorang perawat untuk memprediksi perilaku apa yang akan dilakukan. Dalam hal ini perilaku dari perawat akan baik berasal dari motivasi perawat yang memang baik. Jadi apabila seorang perawat memiliki motivasi yang baik untuk mencapai tujuannya, maka kinerja akan meningkat. Meningkatnya kinerja perawat, dalam penelitian ini menyangkut asuhan keperawatan, akan meningkat pula kinerja rumah sakit tersebut. Dengan demikian, makin meningkatnya motivasi perawat secara individu akan meningkatkan kinerja individu, kelompok maupun rumah sakit tersebut.

Penelitian yang dilakukan oleh Sengkey, $d k k$ mendapatkan bahwa ada hubungan yang bermakna antara motivasi dengan kinerja perawat di IRD Medik BLU RSUP Prof. dr. R. D. Kandou Manado. ${ }^{9}$ Penelitian yang dilakukan oleh Indrawaty dan Rattu mendapatkan bahwa ada hubungan yang signifikan antara motivasi dengan kinerja perawat di Irina Rumah Sakit Datoe Binangkang Kota Kotamobagu. $^{10}$ Penelitian yang dilakukan Mahendra dan Brahmasari mendapatkan bahwa ada hubungan yang signifikan antara motivasi kerja dengan kinerja perawat pelaksana di Ruang rawat inap RSJ Menur Surabaya. Penelitian yang dilakukan oleh Muttaqillah, $d k k$ mendapatkan bahwa motivasi kerja yang diberikan oleh perawat pada BLUD RSJA mempunyai pengaruh positif terhadap peningkatan kinerja perawat. ${ }^{12}$

b. Hubungan antara Kompetensi Perawat dengan Kinerja Perawat dalam Menerapkan Asuhan Keperawatan di Rumah Sakit Umum Bethesda GMIM Tomohon

Berdasarkan hasil analisis bivariat dengan menggunakan uji Chi-square didapat bahwa nilai $\mathrm{p}=0,409$. Nilai $\mathrm{p}>$ 0,05 menunjukkan bahwa tidak terdapat hubungan yang signifikan antara kompetensi perawat dengan kinerja perawat dalam menerapkan asuhan keperawatan di Rumah Sakit Umum Bethesda GMIM Tomohon.

Kompetensi yang merupakakn kemampuan seseorang untuk dapat bekerjasama dipengaruhi oleh pengetahuan 
seseorang tetntang apa yang dikerjakan atau keterampilan melaksanakan pekerjaan tersebut. Tapi hal tersebut tidak hanya sampai disitu, kompetensi juga termasuk membuat produk dan teknologi yang dibutuhkan. Dalam hal ini perawat bukan hanya menerapkan asuhan keperawatan saja tapi perawat juga dapat mengembangkan kemampuan yang dimiliki supaya pasien puas atas pelayanan yang diberikan.

Dalam penelitian ini kompetensi yang meliputi pengetahuan yang cukup tentang SOP dalam melaksanakan asuhan keperawatan, mempunyai pengetahuan yang cukup tentang job description dalm melaksanakan asuhan keperawatan, mempunyai kemampuan untuk mengatasi permasalahan yang timbul dalam melaksanakan asuhan keperawatan, mempunyai keterampilan yang cukup dalam melaksanakan tindakan keperawatan sesuain SOP yang ada, mampu mengoperasikan peralatan medis yang ada dalam mendukung pelaksanaan tugas, mampu untuk berkomunikasi yang baik dengan pasien yang dirawat, hubungan saya dengan profesi lain cukup harmonis, bisa membina hubungan yang baik dengan pasien yang dirawat, mampu melaksanakan semua yang diberikan sesuai target dan dapat bekerja sama dalam satu tim keperawatan yang ada tidak memiliki engaruh terhadap kinerja perawat. Kompetensi perawat yang dilihat disini adalah kompetensi yang memeragakan perilaku pada saat memberikan pelayanan sehingga kompetensi yang dinilai tidak memiliki hubungan dengan penerapan kinerja di Rumah Sakit Bethesda Tomohon.

Tidak ada hubungannya kompetensi dengan kinerja kemungkinan terjadi karena variasi kompetensi terlalu luas, tidak hanya terhadap perilaku dan pengetahuan saja. Hasil yang mungkin berbeda jika kompetensi difokuskan pada tipe, katagori atau hal lain yang berkaitan dengan kompetensi.

Jika merujuk kepada definisi kompetensi seharusnya memang ada hubungan kompetensi dengan kinerja, dimana salah satu definisi kompetensi adalah suatu kemampuan untuk melaksanakan suatu pekerjaan yang dilandasi atas keterampilan dan pengetahuan serta sikap yang dituntut oleh pekerjaan tersebut. Kompetensi terbentuk dengan adanya keselarasan antara mental dan keterampilan fisik. Tidak jarang dijumpai ada karyawan yang sangat termotivasi namun tidak memiliki kemampuan dan keterampilan yang diperlukan sehingga tidak bisa bekerja dengan baik. $^{13}$

Penelitian yang dilakukan oleh Mulyono et al. ${ }^{13}$ mendapatkan bahwa tidak ada hubungan antara kompetensi perawat dengan kinerja perawat di Rumah Sakit Tingkat III 16.06.01 Ambon. Penelitian yang dilakukan oleh Langingi ${ }^{14}$ mendapatkan ada hubungan antara kompetensi dengan kinerja perawat pelaksana di Instalasi Rawat Inap C RSUP Prof. Dr. R. D. Kandou Manado.

c. Hubungan antara Supervisi Pimpinan dengan Kinerja Perawat dalam Menerapkan Asuhan Keperawatan di Rumah Sakit Umum Bethesda GMIM Tomohon

Berdasarkan hasil analisis bivariat dengan menggunakan uji Chi-square didapat bahwa nilai $\mathrm{p}=0,019$. Nilai $\mathrm{p}<$ 0,05 menunjukkan terdapat hubungan yang signifikan antara supervisi pimpinan dengan kinerja perawatdalam menerapkan asuhan keperawatan di Rumah Sakit Umum Bethesda GMIM Tomohon.

Supervisi merupakan bagian penting dari manajemen keperawatan, karena dengan supervisi dapat mengatasi masalah dalam organisasi dengan cepat. Tugas pengawasan atau supervisi tidak bisa dipisahkan dari fungsi kepemimpinan. Supervisor atau pengawas di mata karyawan dianggap sebagai figur ayah dengan peran yang bukan hanya mengawasi, mengarahkan juga harus bisa menampung segala keluhan baik yang berkaitan dengan pekerjaan maupun masalah-masalah pribadi yang menghambat saat bekerja. Superviser juga harus mengetahui sejauh mana kemampuan 
bawahannya dan tingkat kerja samadiantara karyawan yang dibawahinya. Superviser harus mampu turun tangan untuk membantu memecahkan masalah tersebut tanpa menunda-nunda. Sehingga dapat tercipta suasana kerja yang nyaman dan menyenangkan. Seorang supervisor juga harus mampu memotivasi karyawan dalam bekerja dan menyelesaikan tugas-tugas misalnya dengan memberikan pujian atau penghargaan atas apa yang telah dilakukan oleh karyawan dengan hasil yang baik dan sesuai dengan apa yang diharapkan. Hal tersebut selain dapat memacu semangat kerja karyawan juga dapat meningkatkan kepuasan kerja karyawan. ${ }^{15}$

Penelitian ini selalu mengikuti pertemuan yang dilakukan oleh pimpinan untuk pengarahan, dapat mengerti dengan baik setiap arahan yang diberikan oleh Pimpinan, terlibat secara aktif dalam setiap rapat atau pertemuan perawat ruangan, tindakan keperawatan biasanya dikonsultasikan terlebih dahulu dengan pimpinan, biasa melakukan komunikasi dengan atasan terhadap tugas-tugas keperawatan, komunikasi antara atasan dan bawahan berjalan lancer secara dua arah, pembinaan yang dilakukan oleh pimpinan selalu diterima dengan senang hati, arahan dan pembinaan dari pimpinan selalu dijalankan dengan sebaik-baiknya, kepala ruangan melakukan supervisi secara kontinu terhadap pekerjaan dan saat supervisi dari kepala ruangan selalu berada di tempat dapat meningkatkan kinerja perawat dalam menerapkan asuhan keperawatan di RSU Bethesda GMIM Tomohon.

Penerapan pendekatan yang diperuntukkan kepada pendokumetasian asuhan keperawatan merupakan suatu kegiatan supervisi yang dapat dilakukan oleh pimpinan maupun kepala ruang. Dengan adanya supervisi diharapkan memberikan pengarunh terhadap asuhan pendokumentasian keperawatanyang baik sehingga penilaian kinerja yang profesional dan legal bisa dipertanggung jawabkan. Perawat yang melakukan pendokumentasian asuhan keperawatan adalah aspek yang harus diberikan perhatian dan pengertian sehingga apa yang dilakukan bisa didokumentasikan dengan baik dan benar.

Penelitian yang dilakukan oleh Syahrir et al. ${ }^{16}$ mendapatkan bahwa ada hubungan antara supervisi dengan pelaksanaan asuhan keperawatan di ruang rawat inap Rumah Sakit Umum Daerah Labuang Baji Makassar. Penelitian yang dilakukan oleh Hartati dan Handoyo ${ }^{17}$ mendapatkan bahwa ada hubungan antara supervisi dengan pelaksanaan dokumentasi proses keperawatan di Intalasi rawat inap RSUD Perbalingga. Penelitian yang dilakukan oleh Yanti dan Warsito ${ }^{18}$ mendapatkan bahwa ada hubungan antara supervisi dengan kualitas dokumentasi asuhan keperawatan.

d. Hubungan antara Penghargaan dengan Kinerja Perawat dalam Menerapkan Asuhan Keperawatan di Rumah Sakit Umum Bethesda GMIM Tomohon

Berdasarkan hasil analisis bivariat dengan menggunakan uji Chi-square didapat bahwa nilai $\mathrm{p}=0,000$. Nilai $\mathrm{p}<$ 0,05 menunjukkan terdapat hubungan yang signifikan antara sistem penghargaan dengan kinerja perawat dalam menerapkan asuhan keperawatan di Rumah Sakit Umum Bethesda GMIM Tomohon.

Hal-hal yang bisa membuat penghargaan bisa meningkatkan kinerja adalah penghargaan yang telah ada mampu menyentuh aspek profesionalisme dan kinerja perawat. Penghargaan dalam bentuk finansial di RSU Bethesda sesuai dengan dasar perhitungan terhadap sistem grading perawat sehingga bisa menyentuh aspek professional perawat dan kemampuan perawat sehingga hal ini sangat dirasakan oleh perawat sehingga bisa meningkatkan kinerja perawat dan kepuasan pasien.

Dalam penelitian ini penghargaan meliputi atasan memberikan pujian jika bekerja dengan baik, ide-ide didengarkan dan dipertimbangkan oleh atasan, gaji yang diterima sesuai dengan UMP, menerima intensif tambahan jika pekerjaan melebihi target, saat lembur mendapatkan gaji tambahan, puas dengan penghasilan, 
peningkatan karir di rumah sakit berjalan sesuai peraturan, selalu dilibatkan dalam acara rumah sakit dan mendapat nilai yang baik dari atasan sehingga perawat bisa meningkatkan kinerjanya.

Berdasarkan hasil penelitian ini, menurut peneliti hal yang menyebabkan penghargaan memiliki pengaruh terhadap kinerja adalah terletak pada kekuatan penghargaan itu sendiri yang sangat efektif sebagai motivator perawat dalam bekerja karena kekuatan untuk memotivasi kebutuhan melalui pemberian penghargaan tidak lama. Penghargaan akan semakin kuat memotivasi perawat seiring dengan perjalanan perawat dalam mengembangkan dirinya dan dapat mempengaruhi persepsi individu terkait pemenuhan aspek-aspek motivasi yang bersumber dari penghargaan.

Penelitian yang dilakukan oleh Indrawaty dan Rattu ${ }^{10}$ mendapatkan bahwa ada hubungan antara pemberian imbalan dengan kinerja perawat di Instalasi Rawat Inap Rumah Sakit Datoe Binangkang KotaKotamobagu. Penelitian yang dilakukan Royani $^{19}$ mendapatkan bahwa tidak ada hubungan antara sistem Penghargaan dengan kinerja perawat dalam melaksanakan asuhan keperawatan di Rumah Sakit Umum Daerah Cilegon Banten. Penelitian yang dilakukan oleh Hamsinah et al. $^{20}$ mendapatkan bahwa tidak ada hubungan antara sistem penghargaan dengan kinerja perawat di UPTD RSU Sayang Rakyat.

e. Variabel yang Paling Dominan Berpengaruh terhadap Kinerja Perawat dalam Menerapkan Asuhan Keperawatan di Rumah Sakit Umum Bethesda GMIM Tomohon

Berdasarkan hasil analisis uji bivariat dengan menggunakan uji Chi-square diketahui bahwa variabel bebas motivasi, supervisi pimpinan dan sistem penghargaan memiliki hubungan terhadap terhadap kinerja perawat dalam menerapkan asuhan keperawatan di Rumah Sakit Umum Bethesda GMIM Tomohon. Pada analisis multivariat dengan metode regresi logistik menunjukkan bahwa variabel penghargaan merupakan variabel yang paling berperan terhadap kinerja perawat dengan nilai OR = 16,5 (CI 95\% = 3,4-91,0) dibandingkan supervisi $(\mathrm{OR}=0,4$; CI 95\% =0,0-3,9). Hal ini berarti dengan perawat dengan sistem penghargaan yang baik kemungkinan 16,5 kali akan membuat kinerja baik dibandingkan sistem penghargaan yang tidak baik.

Salah satu upaya yang dilakukan oleh suatu instansi, dalam hal ini adalah rumah sakit, dalam meningkatkan kinerja perawat yaitu dengan pemberian penghargaan, baik dalam bentuk barang ataupun gaji tambahan. Pemberian penghargaan ini merupakan salah satu usaha dalam meningkatkan kualitas dan kinerja perawat dalam memenuhi kebutuhan perawat. Perawat akan bekerja lebih semangat dam sesuai dengan harapan dari rumah sakit jika rumah sakit memperhatikan dan memenuhi kebutuhan perawat, baik materi maupun non materi.

Jadi berdasarkan hasil penelitian ini dengan adanya sistem penghargaan yang baik bisa membuat perawat termotivasi dalam melakukan pekerjaannya. Jika perawat termotivasi dalam pekerjaannya dan mendapat dukungan dan supervisi oleh pimpinan rumah sakit, bisa meningkatkan kinerja perawat yang diharapkan bisa membuat puas pasien yang menggunakan rumah sakit akibat pelayanan yang diberikan oleh perawat.

\section{SIMPULAN}

Berdasarkan hasil dan bahasan penelitian tersebut di atas dapat disimpulkan bahwa terdapat hubungan antara motivasi, supervisi dan penghargaan dengan kinerja perawat dalam menerapkan asuhan keperawatan di RSU Bethesda GMIM Tomohon Tidak terdapat hubungan antara kompetensi perawat dengan kinerja perawat dalam menerapkan asuhan keperawatan di RSU Bethesda GMIM Tomohon. Penghargaan merupakan variabel yang paling dominan berpengaruh terhadap kinerja perawat dalam menerapkan asuhan keperawatan di RSU Bethesda GMIM Tomohon. 
DAFTAR PUSTAKA

1. Ridwan LF. Pengaruh Motivasi Intrinsik dan Motivasi Ekstrinsik Terhadap Kinerja Perawat Suatu Kajian Literatur. Bandung: Universitas Padjajaran; 2013.

2. IIyas Y. Kinerja, Teori, Penilaiandan Penelitian, Pusat Kajian Ekonomi Kesehatan. Jakarta: FKM UI;2002.

3. Surbanegara. Diamond Health Drill dan Kepemimpinan Dalam Manajemen Rumah Sakit. Yogyakarta: Penerbit Andi, 2005.

4. Anonimous. 2006. Pelatihan Keterampilan Manajerial Sistem Pengembangan Manajemen Kinerja Klinis (SPMKK), Jakarta.

5. Herwyndianata, Balqis, Darmawansyah. Analisis Faktor Yang Berhubungan Dengan Kinerja Perawat Dalam Penerapan Standar Asuhan Keperawatan Di Unit Rawat Inap RSU Anutapura Palu tahun 2013. Makassar: Universitas Hasanudin; 2013.

6. Anwar AA. Hubungan Pengetahuan, Motivasi Dan Supervisi Dengan Kinerja Perawat Dalam Melaksanakan Patient Safety Di RSUP Dr. Wahidin Sudirohusodo [Tesis]. Makassar: Universitas Hasanuddin; 2012.

7. Hasmoko EV. Analisis Faktor-Faktor Yang Mempengaruhi Kinerja Klinis Perawat Berdasarkan Penerapan Sistem Pengembangan Manajemen Kinerja Klinis Di Ruang Rawat Inap Rumah Sakit Panti Wilasa Citarum Semarang [Tesis]. Semarang: Universitas Diponegoro; 2008.

8. Musta'an, Haryanti S. Hubungan antara Motivasi dengan Kinerja Perawat ditinjau dari Dokumentasi Asuhan Keperawatan di RS Paru Dr. Ario Wirawan Salatiga. Jurnal Ilmu Keperawatan Indonesia. 2010;1(1):112.

9. Sengkey JF, Kandou GD, Tilaar CR. 2011. Hubungan antara Karakteristik Individu dan Motivasi Kinerja Perawat di Instalasi Rawat Darurat Medik Badan Layanan Umum RSUP Prof. Dr. R. D. Kandou Manado. JIKMU. 2011;1(3):148-54.

10.Indrawati DP, Rattu AJM. Faktor-faktor yang Berhubungan dengan Kinerja Perawat di Instalasi Rawat Inap Rumah Sakit Datoe Binangkang Kota Kotamobagu. JIKMU. 2012;2(1):4452.

11.Mahendra IGNT, Brahmasari IA. Pengaruh Kepemimpinan terhadap Disipin Kerja dan Kinerja Perawat Pelaksana di Ruang Rawat Inap RSJ Menur Surawaya, Jurnal Ilmu Ekonomi dan Manajemen. 2014;1(1): 22-42.

12.Muttaqillah, Lubis AR, Majid MSA. Pengaruh Stress Kerja dan Motivasi Kerja terhadap Kinerja Perawat Serta Implikasinya pada Kinerja Badan Layanan Umum Daerah Rumah Sakit Jiwa (BLUD RSJ) Aceh. Jurnal Manajemen Pascasarjana Universitas Syiah Kuala. 2015;4(1):144-53.

13.Mulyono HM, Hamzah A, Abdullah AZ. Faktor Yang Berpengaruh Terhadap Kinerja Perawat Di Rumah Sakit Tingkat III 16.06.01 Ambon. Jurnal AKK. 2013;2(1):18-26.

14.Langingi ARC. Hubungan Faktor Internal dan Eksternal dengan Kinerja Perawat Pelaksana di Instalasi Rawat Inap C RSUP Prof. Dr. R. D. Kandou Manado [Tesis]. Manado: Universitas Sam Ratulangi; 2015.

15.Mulyaningsih. Peningkatan Kinerja Perawat dalam Penerapan MPKP dengan Supervisi oleh Kepala Ruang di RSJD Surakarta. Gaster. 2013;10(1):57-70.

16.Syahrir MH, Haskas $\mathbf{Y}$. Hubungan Supervisi dengan Pelaksanaan Asuhan Keperawatan di Ruang Rawat Inap RSUD Labuang Baji Makassar. Jurnal STIKES Nani Hasannudin. 2012;1(1):1-11.

17.Hartati, Handoyo. 2011. Pengaruh Motivasi Dua FAktor Herzberg terhadap Pelaksanaan Dokumetasi Proses Keperawatan di Instalasi Rawat Inap RSUD Purbalingga. Jurnal Ilmiah Kesehatan Keperawatan. 2011;7(1):26-34.

18.Yanti RI, Warsito BE. Hubungan Karakteristik Perawat, Motivasi dan Supervisi dengan Kualitas Dokumentasi Proses Asuhan Keperawatan. Jurnal Managemen Keperawatan. 2013;1(2):107-14. 
Jurnal e-Biomedik (eBm), Volume 3, Nomor 3, September-Desember 2015

19.Royani. Hubungan Sistem Penghargaan dengan Kinerja Perawat dalam Melaksanakan Asuhan Keperawatan di Rumah Sakit Umum Daerah Cilegon Banten [Tesis]. Jakarta: UI; 2010.
20.Hamsinah ST, Kamal A, Haskas Y. Hubungan antara Sistem Penghargaan dengan Kinerja Perawat dalam Melaksanakan Asuhan Keperawatan di Unit Pelayanan Tekhnis Daerah RSU Sayang Rakyat. Jurnal STIKES Nani Hasannudin. 2013;3(4):143-50. 